\title{
Effect of IL-1 and gustducin expression change on bitter taste during fever
}

\author{
Jenny Sunariani \\ Department of Oral Biology \\ Faculty of Dentistry, Airlangga University \\ Surabaya - Indonesia
}

\begin{abstract}
Homeostatic changes in the body, such as fever, cause inflammation, whose one of its impacts is the sense of bitterness inside the mouth. It implies in the reduction of appetite, which may finally result in the reduction of physical condition due to the inadequacy of food intake. It causes the inhibition of healing process, which reduces working productivity. The objective of this study was to identify the mechanism of bitterness due to inflammation, as proved locally in the taste buds of Wistar rats. This study was carried out experimentally using post-test only control design in experimental animals of male Wistar strain Rattus norvegicus. The animals were divided into two groups. First group served as control, while the second group received treatment with Salmonella typhimurium $0.5 \mathrm{ml} / \mathrm{kg} \mathrm{BW}$. Blood sample and tongue incision were taken from the animals. IL-1 was counted, and tongue incision was used for immunohistochemical staining for the variables of gustducin. Data were analyzed using Kolmogorov-Smirnov test for data normality, and followed with comparative test. The discriminant analysis was also done to find the discriminant variable. It was found that there was an increase of biological response of signaling transduction of bitterness in taste buds, as indicated from the increase of gustducin in treatment group or in inflammatory fever condition as compared to control group $(p<0.05)$, but no change of concertation at IL-1 significan whenever there was any change of concertation by unfolding its mechanism. Further studies can be recommended to find the way to inhibit this sense of bitterness. The results are intended to overcome homeostatic disorder in the body to prevent loss of appetite, so that physical endurance can be maintained. It concluded that there is no increase of serum IL-1 expression in fever, but there is a significanly increase of taste buds gustducin. Further studies should focus on gustducin cellular role in other factors that play a role in taste buds signal transduction, either in homeostatic condition or in the condition of homeostatic disorder.
\end{abstract}

Key words: inflammation, bitter taste, gustducin, IL-1

Correspondence: Jenny Sunariani, c/o: Departemen Biologi Oral, Fakultas Kedokteran Gigi Universitas Airlangga. Jln. Mayjend. Prof. Dr. Moestopo no. 47 Surabaya 60132, Indonesia. Telp. 62-31-5030255. E-mail: jennymdtc@ yahoo.com

\section{INTRODUCTION}

Oral cavity is the early site of entrance of food and the taste of food is determined by the sense of taste or the receptor of the sensation of taste in oral cavity, particularly the tongue. The taste of food is also determined by individual perception on the food itself. Nutrition is one of human basic needs required as the source of energy for the body. The fulfillment of nutritional requirement depends on the appetite, which is affected by central and peripheral nervous systems. In central nervous system, it is influenced by several factors, such as memory of the food, while in peripheral nervous system it is determined by the receptor of taste sensation. ${ }^{1,2}$ Homeostatic disorder in the body, such as infection, may result in the reduction of appetite. The reduction of appetite may occur either at central level, which is in brain, or peripheral level, in the receptor of taste or taste buds. Predominant change of taste into bitterness may reduce appetite, so that it may also reduce body endurance, which may finally result in the reduction of immunologic endurance of the body. The latter will then lead to aggravate infection. ${ }^{3}$ Therefore, fever may result in the reduction of body endurance of working productivity of the patient. ${ }^{4}$ However, the mechanism of appetite reduction in taste receptor within taste buds through signal transduction in inflammatory fever has not been disclosed.

There are several tastes in oral cavity: salty, sour, sweet, bitter, and umami. ${ }^{5,6}$ The occurrence of bitterness results from the binding of chemical substances as the stimulator of the sense of bitterness in the receptor. ${ }^{7-9}$ This reaction makes the Gprotein to release alpha unit, which, in bitter receptor it is called as gustducin. ${ }^{10,11}$ Gustducin activates enzyme, so that in such condition it results in blocked $\mathrm{K}^{+}$channel, and stimulates PLC (phospholipase C) to activate PIP (phosphoinositol phosphate) to become $\mathrm{IP}_{3}$ (inositol triphosphate). $\mathrm{IP}_{3}$ (inositol triphosphate) causes $\mathrm{Ca}^{2+}$ release from endoplasmic reticulum and mitochondria, resulting in depolarization. ${ }^{12,13,14}$ Increased $\mathrm{Ca}^{2+}$ expression within bitter taste receptor cells causes intensified bitterness and delivered further to the memory in brain. ${ }^{15,16}$

One manifestation of homeostatic disorders is inflammatory fever, either endogenous or exogenous. Fever is one of clinical symptoms of infection resulting from bacteria, such as typhoid fever, in which there is a typical symptom in the tongue, called as typhoid 
tongue. Histopathological examination reveals an increase of polymorphonuclear (PMN) inflammatory cells, the neutrophil, which is also a typical sign of acute inflammation. ${ }^{15}$ In fever, the clinical manifestation of infection, there is also a predominant symptom of intensified bitterness in tongue. Physiobiologically, the function of taste receptor is acted by taste buds. The mechanism of taste stimulation is commenced by the presence of primary taste in oral cavity by taste buds as the receptor of taste nerve cells, the part of the body that induces biological response. ${ }^{17}$ The response can be triggered by the exposure of bacteria as signaling initiation. ${ }^{18,19}$

In inflammatory fever, the mechanism of change at cellular level in taste receptor on intracellular molecular changes may occur through ion signal transducing, such as $\mathrm{K}^{+}, \mathrm{Ca}^{2+}, \mathrm{Mg}^{+2}$. Until today, the mechanism of taste buds biological change due to bacteria infection modulation has not been investigated and clearly unfolded. Since there is a clinical symptom of bitterness in inflammation and fever and also changes at cellular level, a detailed study is needed on unclear physiobiological dynamics in predominant changes of bitter taste at peripheral level. This study was conducted on Wistar strain rats (Rattus norvegicus) exposed to Salmonella typhimurium. The observation was carried out on tongue incision for IL-1 expression. ELISA test was done to find gustducin count and histopathological examination was undertaken using immunohistochemical staining. We investigated whether there was an increase of serum IL-1 expression and gustducin count in taste buds.

\section{MATERIALS AND METHODS}

This was a true experimental study using post-test only control group design. Materials used were serum and the incision of Wistar strain Rattus norvegicus rats tongue invaded with bacteria through injection with the bacteria Salmonella typhimurium. Serum IL-1 expression was measured using Elisa method, ${ }^{20}$ and tongue incision was stained immunohistochemistry using monoclonal antibody produced by Santa Cruz Biotechnology, Inc., to observe gustducin expression. This study was undertaken at the Departments of Biochemistry, Microbiology, Anatomic Pathology, and Gramik, Airlangga University School of Medicine, Laboratory of Veterinary Immunology, Airlangga University School of Veterinary Medicine, and Regional Health Laboratory, Surabaya.

In this study, the experimental animals were divided into two groups. Group I served as control group and group II as treatment group that was rendered to have fever. The experimental animals were allocated randomly, treated adequately and ethically eligible. In group I, the animals were injected with distilled water, and in group II the experimental animals received treatment (fever).
Their early temperature was measured and they were injected with Salmonella typhimurium of $0.5 \mathrm{ml} / \mathrm{kg} \mathrm{BW}$. After 6 hours, the final body temperature was measured. They were sacrificed to take their blood and tongue. Serum IL-1 was measured in blood serum, while paraffin blocks were made on the tongue, which was followed with immunohistochemical staining to measure gustducin expression in taste buds.

Experimental animals that experienced inflammation were those rendered to have fever by administered with Salmonella typhimurium and had temperature increase above normal $\left(36^{\circ} \mathrm{C}\right)$. IL-1 is cytokine produced by hypothalamus and measured in the serum of cardiac blood with Elisa. ${ }^{20}$ Gustducin was Gprotein subunit alpha expressed by TRCs of circumvalate papillae taste buds in posterior tongue in inflammation and control groups, measured based on the number of brownish TRCs seen after immunohistochemical staining under light microscope at 400 times magnification.

\section{RESULTS}

Prior to data analysis, statistical test was conducted using Kolmogorov-Smirnov test to find data normality. From the analysis it was found that the samples had normal distribution ( $p>0.05)$. Mean and standard deviation of the variable of inflammation in the examination of temperature and histopathological examination of the tongue in control and treatment groups can be seen in table 1 .

Table 1. t-Test on the variable of systemic inflammatory response

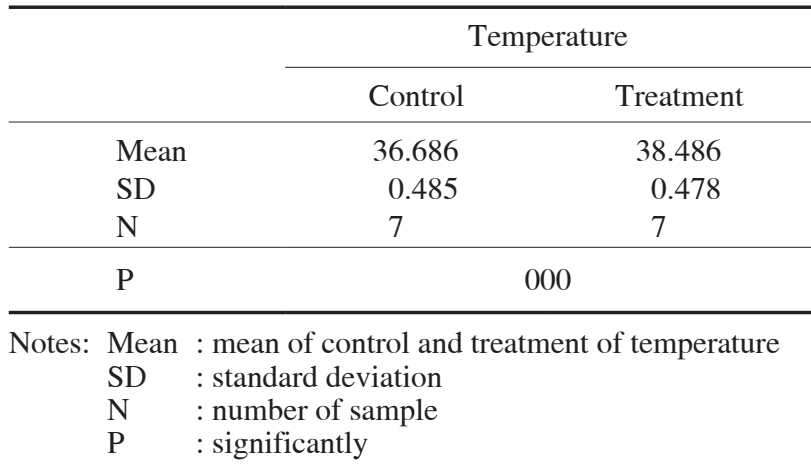

Table 1 shows that there is difference in control and treatment group. The mean in treatment group is higher than that in control group. This indicates that after injection or bacterial invasion, body temperature in those rats was increasing. Statistical analysis revealed mean and standard deviation as displayed in Table 2. 
Table 2. Results of IL-1 and taste buds gustducin measurement

\begin{tabular}{llcc}
\hline \multicolumn{1}{c}{ Group } & N & Mean & Std. Deviation \\
\hline IL-1 Control & 7 & 45.7275 & 22.5943 \\
Treatment & 7 & 49.6536 & 29.9844 \\
Gustducin Control & 7 & 0.38095 & 0.10516 \\
Treatment & 7 & 0.69722 & 0.12067 \\
\hline
\end{tabular}

Notes: N: sample number, Mean: mean of IL-1 and gustducin expression

In treatment group, mean IL-1 showed no significant difference, while comparative test between treatment and control group showed significant difference $(\mathrm{p}<0.001)$ of gustducin in treatment group, while IL-1 also showed difference, but not significant.

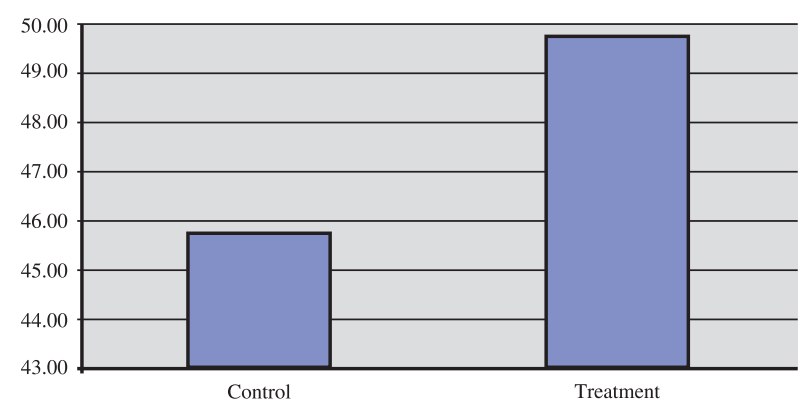

Figure 1. Mean of IL-1 expression

The result of univariate analysis of each IL-1 variable, the result of univariate analysis in treatment and control group using t-Test showed no significant difference of the variables in treatment group.

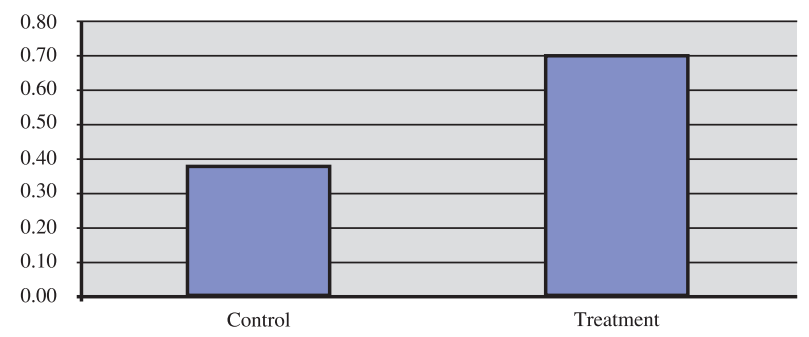

Figure 2. Gustducin expression

The results of univariate analysis of the variables of IL-1 and gustducin in treatment and control group using t-Test revealed significant difference of the variables in treatment group. This indicated that those rats were in inflammatory condition after being exposed to Salmonella typhimurium, which intensified the sense of bitterness.

\section{DISCUSSION}

Various homeostatic disorders in the body may occur due to several factors, one of which is inflammation that

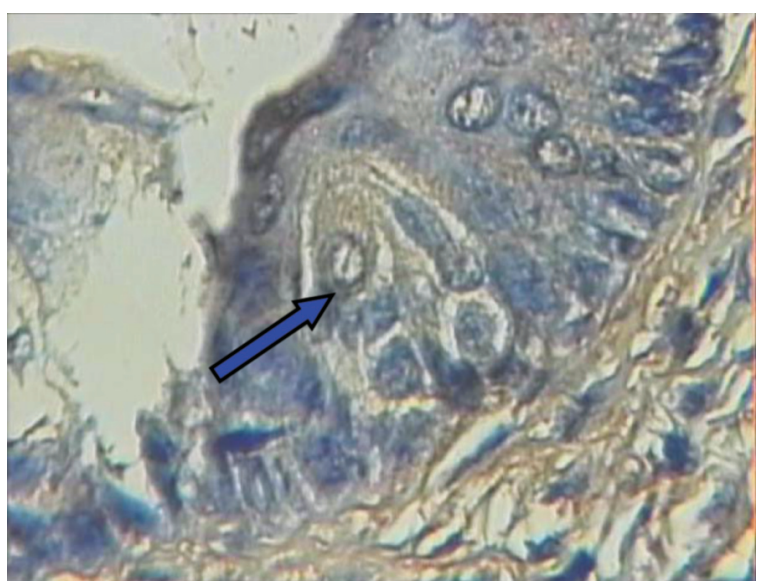

Figure 3. Results of immunohistochemical staining with gustducin antibody, on circumvalate papillae taste buds in normal group, showing blue TRCs $(\longrightarrow)$, magnification 400 times.

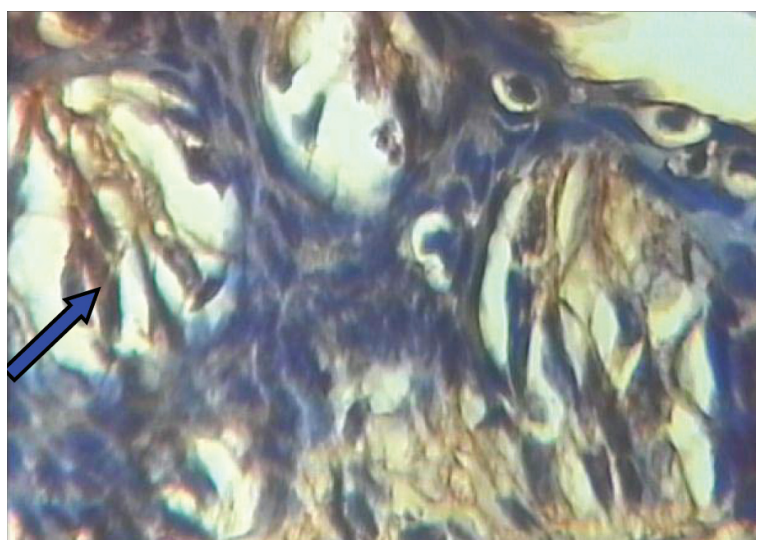

Figure 4. Results of immunohistochemical staining with monoclonal antibody on gustducin, on circumvalate papillae taste buds in treatment group, showing brown TRCs ( $\longrightarrow$ ), magnification 400 times.

may induce clinical symptoms, such as fever. The disorder may also result in changes of taste sensed by peripheral nerve in taste buds, and also result in biological changes of cells, which is presenting as the change of intracellular signaling. This condition may affect the appetite, a clinical manifestation of the presence of inflammation. Reduced appetite may present as a change of the sense of taste, particularly the intensification of bitterness. The quality of food taste may change, resulting from two factors, the food itself and the presence of systemic change in the body beyond the taste cells. Food taste perception depends on taste receptor in taste buds, on other co-stimuli that result from stimulation of somatic taste receptor of the food, on the presence of memory of the food in central nervous system, and the transmission of food perception through taste pathway. To support the idea in this study, a preliminary study had been undertaken using questionnaire to 63 respondents who suffered from fever. The results showed that $96.82 \%$ of the patients had intensified bitterness in the mouth, while only $3.18 \%$ ( 3 persons) felt the intensification 
of sour. Based on the findings in this preliminary study, this study tried to unfold the mechanism of homeostatic disorder in inflammatory fever and sense of bitterness as observed from several molecular variables in the taste cells, such as IL-1 and gustducin.

This study observed biological response of taste buds based on appetite reduction in patients with infection and fever, by using Wistar strain Rattus norvegicus that were invaded with Salmonella typhimurium to find the homogeneity of the cause of fever. The aim of Salmonella administration was to provide condition similar to typhoid fever in human. ${ }^{21}$ This disease is commonly found in tropical population, such as that in Indonesia, with symptoms of reduced appetite due to the intensification of bitterness. Salmonella typhimurium was used because if those rats were given with Salmonella that invades human, fever would not occur, since rats are animals that live in dirty places. $^{22}$

To find whether the samples had normal distribution, we conducted analysis using Kolmogorov Smirnov test, and the result of analysis revealed that data distribution was normal ( $p>0.05$ ). This study was conducted to two groups. The first group was control to obtain data on samples in healthy condition, and the second group received Salmonella typhimurium invasion to induce fever. Various factors affect the occurrence of inflammatory fever, such as the formation of prostaglandin E2, whose EP3 receptor is related with heat, and nitric oxide (NO) that has an important role in inflammation during the eosinophil infiltration. ${ }^{23,24,25}$

To empiricize the biologic response variable, we conducted statistical comparative analysis using t test. To prove the presence of inflammation, we undertook temperature measurement and blood sampling for serum IL-1 expression. It was found that there was a significant increase of temperature, indicating that the rats were infected with Salmonella typhimurium. To prove the change of gustducin expression and IL-1 expression in both groups, two sample t-Test was undertaken. Results of examination in experimental animals injected with Salmonella typhimurium of $0.5 \mathrm{cc} / \mathrm{kg} \mathrm{BW}$, which was equal to McFaland III solution, revealed the occurrence of fever in inflammation, presenting as the increase of acute inflammatory cells, i.e. polymorphonuclear cells, particularly the neutrophil (63\%), as proved by histopathological test. ${ }^{26}$ By the presence of acute inflammation as indicated by clinical symptoms of inflammatory fever, further identification of other biological variables, i.e., serum IL-1, was conducted using Elisa and gustducin examinations through immunohistochemical staining.

The results showed that during inflammation, clinical symptom that presents as fever is apparent, particularly acute inflammation. This was indicated by the increase of serum IL-1 expression, which was an inflammatory cytokine produced by macrophage or other APC due to the invasion of Salmonella typhimurium. Although mean IL-1 expression did increase in treatment group, the increase was not significant, but systemically it had showed the occurrence of temperature increase. This was likely due to the presence of other inhibiting factors or due to untimely sampling time. Sampling was undertaken after the reduction of IL-1 level, as IL-1 is a sensitive cytokine, so when it had been measured at lower level, the result would appear to be less significant. In addition, IL-1 is an inflammatory cytokine produced by macrophage, and it is the only cytokine that has natural inhibitor. The inhibitor is recognized as IL-1 receptor antagonist (IL-1RA), an endogenous regulator for IL-1 activity. There are also other factors that may inhibit IL-1 production in certain conditions, such as the activity of $\mathrm{CD}^{+}$cells. ${ }^{3}$

Data analysis showed significant increase $(p<0.05)$ in biological marker, the gustducin (Gprotein subunit alpha) in bitterness taste within treatment group. The increase of gustducin expression in TRC is marked by the absorption of immunohistochemical materials that renders the taste buds color to become brownish. During inflammation, there is an increase of PGE2. ${ }^{2,27}$ The inflammation activated EP3 receptor, which is the receptor of $\mathrm{PGE} 2$, and $\mathrm{EP} 3$ receptor will receive heat information that mobilizes $\mathrm{Ca}^{2+}$, resulting in the increase of receptor sensitivity to stimulate adenilate cyclase. ${ }^{23}$ The increase results in Gprotein binding, which activates PLC, and PLC activation results in PIP breaking to become $\mathrm{IP}_{3}$ and DAG. $\mathrm{IP}_{3}$ binding with ER receptor stimulates $\mathrm{Ca}^{2+}$ release from mitochondria and endoplasmic reticulum and results in the opening of ER membrane $\mathrm{Ca}^{2+}$ channel, so that $\mathrm{Ca}^{2+}$ is released toward cytosol. ${ }^{28} \mathrm{Ca}^{2+}$ is also released from endoplasmic reticulum when there is stimulation from PGE2, which results in depolarization, and this condition leads to the transduction of bitter taste to the brain. ${ }^{23,29,30}$

Structural and chemical diversity of the tastant leads to various transduction mechanisms. This was different from that occurs in the sense of vision and olfaction, whose stimulation only runs through general stimulation pathway by the presence of photon or small volatile molecules transduced through a basic mechanism. ${ }^{31}$ This study was only viewed the role of signaling cells in peripheral nerves by confirming the biological change in elements that run the complex sense of taste transduction. The element of gustducin presents within the taste buds. It has a role in the transmission of the sense of taste, and the mechanism of each taste has its own specification. The receptor 7-transmembrane helix has a role to commence signaling cascade by binding the Gproteins. ${ }^{15,32,33}$

The sense of taste in oral cavity may change if there is homeostatic change in the body, such as in a condition of natrium ion loss, in which taste receptor related to natrium ion channel has sensitivity reduction against the taste of salt, and so does other receptors. Transduction and coding depend on TRCs input through afferent nerve fibers. The information codes the taste quality that depends on comparative pattern in the fibers. Each nerve fiber has specification according to their sensitivity against particular taste. For example, in fiber sensitive against salt, the nerve fiber has a high sensitivity against the taste of salt, but it can also sense other tastes in a lower sensitivity. 2,34 
The entrance of $\mathrm{Ca}^{2+}$ into cytosol in membrane damage generally occurs due to injury ${ }^{35,36}$ or intoxication. This results in the change of $\mathrm{Ca}^{2+}$ expression within cytosol and results in cell death. ${ }^{37}$ Most of cytosol $\mathrm{Ca}^{2+}$ is preserved particularly within reticulum endoplasma and mitochondria, as well as other vesicles in lower amount. $\mathrm{Ca}^{2+}$ ATPase pumps the $\mathrm{Ca}^{2+}$ in the cytosol to cross the plasma membrane outward or to the preservation site within reticulum endoplasma and mitochondria. Minute $\mathrm{Ca}^{2+}$ increase from normal within cytosol may result in various cellular responses, such as the stimulation of the sense of bitterness in gustducin. Excessive and continuous increase of $\mathrm{Ca}^{2+}$ within cytosol leads to cellular intoxication. In this case it was manifested as inflammatory fever. ${ }^{15}$

It concluded that there is no increase of serum IL-1 expression in fever, but there is a significanly increase of taste buds gustducin. Further studies should focus on gustducin cellular role in other factors that play a role in taste buds signal transduction, either in homeostatic condition or in the condition of homeostatic disorder.

\section{REFERENCES}

1. Carlson NR. Physiology of Behavior. $5^{\text {th }}$ ed. Boston: Allyn and Bacon; 2000. p. 213-7.

2. Guyton AC, Hall JE. Textbook of medical physiology. $11^{\text {th }}$ ed. Philadelphia: Elsevier Saunders Comp; 2006. p. 44-8, 54, 61, 87-9, $76-8,567,675-80,725,758,771$.

3. Kresno SB. Imunologi: Diagnosis dan prosedur laboratorium. Edisi ke 4. Jakarta: Fakultas Kedokteran Universitas Indonesia; 2001. p. 3-58, 65-90.

4. Mandel GL, Bennett JE, Dolin R. Principles and practice of infectious diseases. $4^{\text {th }}$ ed. New York: Churchill Livingstone; 1995. p. 569-607.

5. Adler E, Hoon MA, Mueller KL, Chandrashekar J, Ryba NJP, Zuker CS. A novel family of mammalian taste receptors. Rev by John Palma of Cell 2000; 100:693-702.

6. Jacob T. A Brief tutorial. Available: http://www.cf.ac.uk/biosi/ stsff/jacob/teaching sensory/ taste/ html. Updates in $1^{\text {st }}$ of February 2008.

7. Ogura T, Mackay-Sim A, Kinnamon SC. Bitter taste transduction of denatonium in the mudpuppy necturus maculosus. $\mathrm{J}$ of Neurosci 1997; 17(10):3580-7.

8. Zald DH, Hagen MC, Pardo JV. Neural correlates of tasting concentrated quinine and sugar solutions. J of Neurophys 2002; 87(2):1068-75.

9. Yan C, Kim D, Aizawa T, Berk BC. Functional interplay between angiotensin II and nitric oxide cyclic GMP as a key mediator. Arterioscler Thromb Vasc Biol 2003; 23:26-36.

10. Kusakabe Y, Miura H, Hashimoto R, Sugiyama C, Ninomiya Y, Hino A. The neural differentiation gene mash-1 has a distinct pattern of expression from the taste reception-related genes gustducin and T1R2 in the taste buds chem. Senses 2002; 27:445-51.

11. Jansen G, Weinkove D, Plasterk RHA. The G-protein subunit gpc-1 of the nematode C. elegans is involved in taste adaptation. EMBO 2002; 21(5):986-94.

12. Ogura T, Kinnamon SC. $\mathrm{IP}_{3}$-Independent Release of $\mathrm{Ca}^{2+}$ From Intracellular Stores: A Novel Mechanism for Transduction of Bitter Stimuli. J of Neurophys 1999; 82(5):2657-66.

13. Akopian A, Withowsky P. Intracellular calcium reduces light-induced excitatory post-synaptic responses in salamander retinal ganglion cells. J of Phys 2001; 532(1):43-53.

14. Ando H, Mizutami A, Matsu-Ura, Mikoshiba K. IRBIT, a Novel Inositol 1,4,5-Triphosphate $\left(\mathrm{IP}_{3}\right)$ receptor-binding protein, is released from the $\mathrm{IP}_{3}$ receptor upon $\mathrm{IP}_{3}$ Binding to the receptor. J of Biol Chem 2003; 278(12):10602-12.

15. Ganong WF. Review of Medical Physiology. $19^{\text {th }}$ ed. Seoul: McGrawHill Publ; 2001. p. 37-46:59-60, 90-110, 180-1, 183-7, 242, $249,382$.

16. Vander A, Sherman J, Luciano D. Human Physiology. The mechanism of body function. $8^{\text {th }}$ ed. New York: McGraw-Hill; 2001. p. 262-70.

17. Purves D, Augustine GJ, Fitzpatrick, Katz LC, LaManta AS, McNamara JO. Neuroscie. Massachussets: Sinauer Assc; 1997. p. 273-97.

18. Stewart RE, DeSimone JA, Hill DL. New perspectives in a gustatory physiology: transduction, development, and plasticity. AJP - Cell Phys 1997; 272 (1):C1-26.

19. Goldsby RA, Kindt TJ, Osborne BA. Kuby immunology. $4^{\text {th }}$ ed. New York:. WH Freeman and Co; 2000. p. 351-5, 365-9.

20. Arondel J, Singer M, Matsukawa A, Zychlinsky A, Sansonetti PJ. Increased Interleukin-1 (IL-1) and Imbalance between IL-1 and IL-1 receptor antagonist during acute inflammation in experimental shigellosis infection and immunity. 1999. 67(11):6056-66.

21. Faucher SP, Porwollik S, Dozois CM, McClelland M, Daigle F. Transcriptome of Salmonella enterica serovar Typhi within macrophages revealed through the selective capture of transcribed sequences. Medicine Sci 2006; 22(10):792-3.

22. Hill CH. Effect of Salmonella gallinarum infection on zinc metabolism in chicks. Poultry Science 2001; 68(2):297-305.

23. Hatae N, Sugimoto Y, Ichikawa A. Prostaglandin receptor: Advances in the study of EP3 receptor signaling. Bioc Soc 2002; 131(6):781-4.

24. Hull MA, Ko SCW, Hawcroft G, Prostaglandin EP receptors: Targets for treatment and prevention of colorectal cancer. Cancer Resr 2004; 3:1031-9.

25. Nguyen MT, Solle M, Audoly LP, Tilley SL, Stock JL, McNeish JD, Coffman TM, Dombrowicz D, Koller BH. Receptor and signaling mechanisms required for prostaglandin E2-mediated regulation of mast cell degranulation and IL-6 production. American Assoc of Immunologists 2002; 169:4586-93.

26. Gronert K, Colgan SP, Serhan CN. Characterization of human neutrophil and endothelial cell ligand-operated extracellular acidification rate by microphysiometry: Impact of reoxygenation. J Pharmacol Exp Ther 1998; 285(1):252-61.

27. Gallin JI, Snyderman R, Fearon DT, Haynes BF, Nathan C. Inflammation basic principles and clinical correlates. $3^{\text {rd }}$ ed. Philadelphia, USA: Lippincott Williams \& Wilkins; 1999. p. 433-6, 443-51, 837, 1207-11.

28. Spielman AI. Gustducin and its role in taste. J of Dent Res 1998; 77:539-44.

29. Fagni L, Chavis P, Ango F, Bockaert J. Complexs interactions between mGluRs, intracellular $\mathrm{Ca}^{2+}$ stores and ion channels in neurons. TRENDS In Neurosc 2000; 23(2):280-8.

30. Braunwald E, Fauci AS, Kasper DL, Hauser SL, Longo DL, Jameson JL. Harrison's. Principles of internal medicine. $15^{\text {th }}$ ed. Washington DC: McGraw-Hill Publ; 2001. p. 1125-30.

31. Katz DB, Nicolelis MAL, Simon SA. Nutrient tastingand signaling mechanisms in the gut IV. There is more to taste than meets the tongue. Am J Physiol Gastrointest Liver Physiol 2000; 278:G6-G9.

32. Ueda T, Ugawa S, Yamamura H, Imaizumi Y, Shimada S. Functional Interaction between $\mathrm{T} 2 \mathrm{R}$ taste receptors and g-protein a subunits expressed in taste receptor cells. J of Neuroscie 2003; 23(19):7376-80.

33. Boron WF, Boulpaep EL. A cellular and molecular approach. Med phys. Update ed. Philadelphia: Elsevier Saunders; 2005. p. 207, 208, 328-31.

34. Kandel ER, Schwart JH, Jessel TM. Stamfort, A Simon \& Schuster Co. Neuroscience. Massachussets: Sinauer Assc Publ; 2000. p. 273-97.

35. Repo RU, Finlay JB. Survival of articular cartilage after controlled impact. J Bone Joint Surg (Am) 1977; 59:1068-76.

36. Jeffrey S, Fedan. Nucleosides and Nucleotides in the Lung. Am J Respir Cell Mol Biol 1995; 21(1):7-9.

37. Blanco FJ, Guitian R, Vasquez ME, De-Toro FJ, Galdo F. A possible pathway for osteoarthritis pathology. Arth Rheum 1998; 41:284-9. 